7. Child Lang. 42 (2015), I 408-1408. (C) Cambridge University Press 2015 doi:I0.1017/So30500091500050I

CORRIGENDUM

\title{
Attention to the mouth and gaze following in infancy predict language development - CORRIGENDUM
}

\author{
ELENA J. TENENBAUM, DAVID M. SOBEL, STEPHEN \\ J. SHEINKOPF, BERTRAM F. MALLE AND JAMES
}

L. MORGAN

doi:Io.ror7/So3050009I4000725, Published online by Cambridge University Press, I 8 November 2014.

The original version of this paper was missing a co-author from the authors' list: Rajesh J. Shah (unaffiliated). The complete authors' list is reproduced below:

Elena J. Tenenbaum, David M. Sobel, Stephen J. Sheinkopf, Rajesh J. Shah, Bertram F. Malle and James L. Morgan

\section{REFERENCE}

Tenenbaum, E. J., Sobel, D. M., Sheinkopf, S. J., Malle, B. F. \& Morgan, J. L. (2014). Attention to the mouth and gaze following in infancy predict language development. Fournal of Child Language 42, I I73-1 I90. Published online is July 2014, doi: I0.1017/ So305000914000725. 